\title{
Állam- és jogtudományi doktori képzés Magyarországon - akadályok és lehetöségek között (a Marton Géza Doktori Iskola kilencedik tanéve elé)
}

\author{
PhD-képzés - doktori képzés - jogászképzés - MAB - \\ Marton Géza Doktori Iskola - Debreceni Egyetem
}

Jelen tanulmányban megkíséreljük felvázolni a Magyarországon müködő államés jogtudományi doktori iskolák müködésének kereteit, kiegészítve mindezt a „debreceni sajátosságokkal és realitásokkal”, illetve ezek értékelésével. Írásunk, azon túl, hogy ily módon kíván tisztelegni a 2014-ben 100. évét kezdő debreceni jogi oktatás előtt, arról is képet kíván adni, hogy mennyire nehéz dolguk volt és van napjainkban is az intézményeknek (doktori iskoláknak), amikor a folyamatosan változó (időröl időre tendenciózusan szigorodó) feltételek mentén törekednek biztosítani az intézmény jogszabályoknak, MAB-előírásoknak és egyetemi szabályzatoknak megfelelő müködését úgy, hogy közben tekintettel legyenek az íratlan követelményekre és a kimondott vagy ki nem mondott intézményi érdekekre is. ${ }^{1} A$ tanulmány általános áttekintést adó részeinek szerzője Kecskés Gábor, ${ }^{2}$ a debreceni tapasztalatokat bemutató részeké Szemesi Sándor.

\section{A magyarországi doktori képzés történetéröl}

A második világháború után Magyarországon a tudományos fokozat odaítélésére, szovjet mintára, a Magyar Tudományos Akadémia, pontosabban ennek Tudományos Minősítő Bizottsága volt kizárólagosan jogosult, kandidátusi fokozat (CSc vagy

* Dr. Kecskés Gábor egyetemi adjunktus, Széchenyi István Egyetem Deák Ferenc Állam- és Jogtudományi Kar, Nemzetközi Köz- és Magánjogi Tanszék; titkár, Széchenyi István Egyetem Állam- és Jogtudományi Doktori Iskola; tudományos munkatárs, MTA Társadalomtudományi Kutatóközpont Jogtudományi Intézet, kecskesg@sze.hu. Dr. Szemesi Sándor egyetemi docens, Debreceni Egyetem Állam- és Jogtudományi Kar, Európa-jogi és Nemzetközi Jogi Tanszék; titkár, Debreceni Egyetem Marton Géza Állam- és Jogtudományi Doktori Iskola, szemesi.sandor@law.unideb.hu.

1 Például a Miskolci Egyetem Deák Ferenc Állam- és Jogtudományi Doktori Iskolája müködésének első két évtizedét részletesen bemutatja az alábbi kiadvány: STIPTA István: $A$ doktori képzés két évtizede a miskolci jogi karon, Miskolc, Miskolci Egyetem, 2012.

2 Eme részek alapjaként lásd KECSKÉs Gábor: Az állam- és jogtudományi doktori képzés a rendszerváltás után - a doktori iskolák szerepfelfogása. In: Patyi András-Lapsánszky András (szerk.): Rendszerváltás, demokrácia és államreform az elmúlt 25 évben: ünnepi kötet Verebélyi Imre 70. születésnapja tiszteletére, Budapest, Complex, 2014, 297-308. 
C.Sc., azaz Candidate of Sciences) formájában. ${ }^{3}$ A Magyar Tudományos Akadémia doktora (DSc vagy D.Sc., azaz Doctor of Sciences) címet a kandidátusok nyerhették el, csakúgy mint a jelenleg hatályos rendszerben a PhD-fokozattal (vagy DLAfokozattal) rendelkező személyek. A kandidátusi fokozatot a rendszerváltás után felváltotta a PhD (vagy Ph.D., azaz Doctor of Philosophy), illetve művészeti képzési területen a DLA (Doctor of Liberal Arts) mint doktori fokozat, a felsőoktatásról szóló 1993. évi LXXX. törvény alapján. Az elnevezés módosulásán túl a lényegi változást az jelentette, hogy az egyetemek vissza-, illetve megkapták a doktori fokozat odaítélésének jogát, ${ }^{4}$ ugyanakkor a DSc mint tudományos cím odaítélésére továbbra is (helyesen) kizárólag a Magyar Tudományos Akadémia jogosult.

Fontos ugyanakkor megjegyezni, hogy 1984. szeptember 1. után lehetöség nyílt ún. egyetemi doktori fokozat (dr. univ.) megszerzésére is, egészen 1993-ig. Eme tudományos fokozatnak nem minősíthető egyetemi fokozatot (amely egyébként kutatómunkán alapult, és gyakorta magas presztízsü külföldi egyetemeken eltöltött kutatóévek eredményét jelentette) a jogszabályok és aztán a kialakult koherens gyakorlat szerint az 1984 és 1993 közötti időszakban kandidátusi fokozatként (CSc), azaz tudományos fokozatként lehetett elismertetni az MTA Tudományos Minősítő Bizottsága által. A későbbiekben ugyanezt megtehették az egyetemek is, amikor a dr. univ. megjelölést $\mathrm{PhD}$-fokozatként ismerhették el (a gyakorlatban ilyen elismerésre az állam- és jogtudományok területén csak kivételes esetekben került sor). A szerzett jogok megóvásaként, és a gyakorlathoz is igazodva, az 1993-as felsőoktatási törvény továbbra is lehetővé tette a dr. univ. mint tudományos fokozat megjelölés használatát [118. $§(1)$ bekezdés]. Így a dr. univ. alapján (elviekben legalábbis) kandidátusi vagy később $\mathrm{PhD}$-fokozat megszerzésére nyílt lehetőség.

A PhD-t vagy DLA-t mint tudományos doktori fokozatot az 1993-as felsőoktatási törvény vezette be Magyarországon, az egyetemekhez telepítve ezek odaítélésének jogát. Mi több, valamennyi azóta hatályba lépett felsőoktatási törvény szerint az egyetemi lét egyik alapvető követelményévé vált, hogy az intézmény több tudományterületen és tudományterületenként több tudományágban, valamint több szakon (illetve képzési területen) legyen képes és alkalmas PhD-, illetve DLA-fokozat odaítélésére. ${ }^{5}$ Hangsúlyozandó ugyanakkor az is, hogy a kandidátusi fokozat joghatását és tudományos „impaktját” tekintve a mai napig elviekben egyenértékủ a PhDvagy DLA-fokozattal, ám ez az egyenértékűség valójában meglehetősen vitatott

3 Az egyetemek a doktori cím odaítélésének jogával ugyan az 1950-es évektől újra rendelkeztek, ez azonban ténylegesen csak doktori címet jelentett, amely természetesen a klasszikus „doktori” hivatásrendek (jogász, orvos stb.) gyakorlati művelése szempontjából elegendő volt, de doktori, azaz tudományos fokozatként ezt nem ismerték el. Az ilyen doktori címeket képesítő jellegủ doktorátusnak vagy hivatási doktori címnek nevezik.

4 Jelenleg (2014. október 1-jei állapot szerint) állam- és jogtudományi doktori fokozat megszerzésére Magyarországon nyolc doktori iskolában van lehetőség: a Debreceni Egyetemen, az Eötvös Loránd Tudományegyetemen, a Károli Gáspár Református Egyetemen, a Miskolci Egyetemen, a Pázmány Péter Katolikus Egyetemen, a Pécsi Tudományegyetemen, a győri Széchenyi István Egyetemen, valamint a Szegedi Tudományegyetemen. Továbbá az Andrássy Gyula Budapesti Német Nyelvü Egyetem Interdiszciplináris Doktori Iskolájában van lehetőség állam- és jogtudományok tudományágban is doktori tanulmányokat folytatni (http://www.doktori.hu/index.php?menuid=197\&ilD=1\&list=109). A külföldön szerzett doktori fokozatokat ezen állam- és jogtudományi doktori képzési helyeken lehet honosítani.

5 Lásd az 1993. évi LXXX. törvény 3. § (1) bekezdés b) pontját, a 2005. évi CXXXIX. törvény 18. § (3) bekezdését, illetve jelenleg a 2011. évi CCIV. törvény 9 . § (3) bekezdés a) pontját. 
mind a tudományos impakt szempontjából, mind az odaítélő aktorok szintje miatt. ${ }^{6}$ Összegzésképpen elmondható, hogy de iure 1993, de facto pedig 1997 után már kizárólag PhD- vagy DLA-fokozatot lehet szerezni, mégpedig az akkreditált egyetemi képzési helyeken.

\section{A doktori iskolák céljai}

Valamennyi állam- és jogtudományi doktori iskola célja a hazai és nemzetközi jogtudomány fejlesztése és a képzési intézmények hazai és nemzetközi hírnevének öregbítése. Emellett kiemelt célkitűzésként jelenik meg a doktori iskoláknak helyet és intézményes keretet adó egyetemek (ezeken belül karok) személyi feltételeinek javítása, azaz az oktatói utánpótlásképzés biztosítása. Minden felsőoktatási intézmény abban érdekelt, hogy a minősített (doktori fokozattal rendelkező) oktatóinak száma minél magasabb legyen, ez garantálja egyrészröl az oktatói, de leginkább a kutatói potenciál növelését, másrészről ezáltal biztosított az egyetemi portfólió-bövítés és ennek eredményeként a minőségi jogászképzés hosszú távra történő megalapozása. Eme célok természetesen markánsan nem különíthetök és nem is különítendők el, azonban időről időre megfigyelhető némi hangsúly-eltolódás az egyes célok között attól függően, hogy mely idöpillanatban mely doktori iskola müködését vizsgáljuk behatóbban.

Az 1996-ban újrainduló debreceni jogászképzésben 2001-ben került sor az első végzős évfolyam kibocsátására, így elvi szinten ekkortól jelentkezhettek debreceni hallgatók (saját doktori iskola hiányában más egyetemeken folyó) PhD-képzésbe. A kezdeti években a Miskolci Egyetem és a Debreceni Egyetem rektorainak külön megállapodása alapján ${ }^{7}$ a 2001/2002. tanévtöl kezdődően minden évben két nappali tagozatos PhD-hallgató kezdhette meg tanulmányait a Miskolci Egyetem Deák Ferenc Állam- és Jogtudományi Doktori Iskolájában. Ezeket a hallgatói helyeket a Debreceni Egyetem „finanszírozta” oly módon, hogy az egyetem a PhD-keretszámából két féröhelyet minden évben átadott a Miskolci Egyetemnek, az említett megállapodás alapján. ${ }^{8}$ Érdekes azonban, hogy míg a debreceni kari köztudatban ez a megállapodás lényegében automatikusan minden évben járó két $\mathrm{PhD}$-féröhelyként létezett, valójában a Jog- és Államtudományi Intézet, majd 2003-tól az Állam- és

6 Kandidátusi fokozatot az 1990-es évek végéig lehetett szerezni. Egyébiránt a mai napig hallható, hogy függetlenül a mai PhD-fokozatok egyfajta „inflálódásától”, pontosabban: devalválódásától - a kandidátusi fokozat megszerzéséhez szükséges értekezés terjedelmesebb és talán tartalmasabb munka volt, mint a mai PhD-fokozatok megszerzéséhez az egyetemi gyakorlatok szintjén megfogalmazott elvárások. Ez azonban minden bizonnyal annak is köszönhető, hogy az MTA Tudományos Minősítő Bizottsága egységes, a tudományos élet intézményi csúcsszervében megfogalmazott követelményeit kellett a kandidátusi fokozathoz teljesíteni, ellentétben a mai, korántsem egységes, versenyhelyzeten alapuló egyetemi követelményrendszerekkel. Utóbbiak minőségbiztosításáról ugyanakkor természetesen a Magyar Felsőoktatási Akkreditációs Bizottság (a továbbiakban: MAB) gondoskodik.

7 Ennek alapja a Debreceni Egyetem és a Miskolci Egyetem között 2000. július 5-én a debreceni jogászképzés segítése érdekében kötött megállapodás volt.

8 A megállapodásra kifejezetten utal az Állam- és Jogtudományi Kar 2005. márciusi, a MAB jogász szakok párhuzamos akkreditációjára készített önértékelése is: „Karunk minden évben két nappali tagozatos PhD hallgatót delegálhat a ME Deák Ferenc Doktor iskolájába." (sic!), lásd az önértékelés 31. oldalát. 
Jogtudományi Kar vezetésének minden évben igényelnie kellett a két férőhely biztosítását a Debreceni Egyetem tudományos rektorhelyettesén keresztül az Egyetemi Tudományos, Doktori és Habilitációs Bizottságtól. A Debreceni Egyetem és a Miskolci Egyetem tudományos rektorhelyettesei (Berta András és Dobróka Mihály) által 2006. szeptember 15-én kötött megállapodás zárta le a két egyetem közötti együttmüködés ezen szakaszát, miután a 2006/2007. tanévben megkezdte müködését a Debreceni Egyetemen is az állam- és jogtudományi doktori iskola, Horváth M. Tamás vezetésével. ${ }^{9}$ És bár az intézményi (a PhD-hallgatók képzésére irányuló) együttmüködés 2006-ban véget ért, azóta is számos, a Debreceni Egyetemen végzett hallgató és/vagy a Debreceni Egyetemen oktató kolléga szerzett a Miskolci Egyetem Deák Ferenc Állam- és Jogtudományi Doktori Iskolájában PhD-fokozatot. ${ }^{10}$

Egy közel fél évszázados szünet után újrainduló vidéki jogászképzés esetében a doktori képzés célja (a Miskolci Egyetem Deák Ferenc Állam- és Jogtudományi Doktori Iskolájának segítségével) a kezdeti időszakban nem is nagyon lehetett más, mint az említett célok közül az oktatói utánpótlás kinevelése-biztosítása, mely egyértelműen háttérbe szorította a további érveket és szempontokat. Valóban: a Miskolci Egyetemen tanulmányait megkezdő összesen 11 nappali tagozatos „debreceni” doktorandusz közül mindösszesen egy, tanulmányait egy év után abbahagyó kolléga kivételével mindannyian hosszabb vagy rövidebb ideig oktatói tevékenységet is láttak el, vagy látnak el a mai napig is. A 2010 utáni időszakban ugyanakkor már ez a cél (köszönhetően részben a kezdeti évek intenzív személyzetfejlesztési politikájának, részben pedig a folyamatosan változó finanszírozási és képzési környezetnek) egyértelműen háttérbe szorult, és sokkal inkább a hazai és nemzetközi jogtudomány fejlesztésének célja vált központi tényezővé. A Debreceni Egyetem méreteiböl adódóan ugyanakkor megítélésünk szerint az említett célok közül az egyetemi portfólióbővítés soha nem kapott igazán központi szerepet a debreceni állam- és jogtudományi PhD-képzés céljai között.

Bármelyik célt emeljük is ki a fentiek közül (akár általánosságban, akár a debreceni sajátosságokra vetítve), nem téveszthetjük szem elöl, hogy a doktori iskola müködésének fontos, ugyanakkor napjainkban Magyarországon meglehetősen túldimenzionált mérőszáma az adott doktori iskolában fokozatot szerzett PhD-hallgatók számaránya. Mihály György, az Országos Doktori Tanács (ODT) elnöke 2013. június 3-án tartott, „PhD-fokozatok nyomában - adatok és javaslatok” című elöadása ${ }^{11}$ külön is megemlít (nem nevesítve) három olyan állam- és jogtudományi doktori iskolát, melynek feltűnően alacsony a müködési hatékonysága: mindhárom példaként

9 A Marton Géza Állam- és Jogtudományi Doktori Iskola vezetője 2009. február 1. óta Szabó Béla egyetemi tanár.

10 Elsőként 2000-ben Fodor László szerzett a debreceni jogi kar oktatói közül Miskolcon PhD-fokozatot, legutóbb pedig 2014. szeptember 1-jén Újvári Emese nyilvános vitájára került sor. Az eltelt közel másfél évtized alatt összesen 26 debreceni oktató szerzett Miskolcon PhD-fokozatot, közülük egy fő (Árva Zsuzsanna) sub auspiciis fokozatot szerzett, az elmúlt két évtizedben tudomásunk szerint egyetlen jogászként. Árnyalja ugyanakkor a képet, ha hozzátesszük, hogy a 25 oktató közül - életkori meghatározottság miatt -„,mindöszsze" 14 kolléga végezte Debrecenben a jogi tanulmányait.

11 http://www.doktori.hu/index.php?menuid=351\&cid=236 (2014. 09. 30.). Lásd különösen az elöadásvázlat 15. diáját. 
hozott doktori iskolában nagyjából 33\% körüli az összes beiratkozott hallgatóból az abszolutóriumot szerzettek aránya, és csak mintegy $10 \%$ körüli a fokozatot szerzetteké. ${ }^{12}$

Hogy ez a „számfetisizmus” milyen eltérő eredményekre vezet ugyanazon adatsorral dolgozva, jól mutatja, hogy a Marton Géza Doktori Iskolában a 2014. június 30-ig összesen felvett 88 hallgatóból 36 fő (40\%) abszolvált, és csak 13 fő (14\%) szerzett fokozatot, ekként akár azt is megállapíthatnánk, hogy a Marton Géza Állam- és Jogtudományi Doktori Iskola is az alacsony müködési hatékonyságú doktori iskolák közé tartozik. Ha azonban ezt az adatsort azzal korrigáljuk, hogy jelenleg is a doktori iskola PhD-hallgatója további 44 fö (az összes eddig felvett hallgató $50 \%-a)$, akiknek a képzés sajátosságaiból adódóan esélyük sem volt még sem az abszolutórium, sem pedig a PhD-fokozat megszerzésére, akkor máris azt állíthatjuk, hogy azon 44 hallgató közül, akiknek potenciálisan volt esélye már az abszolutórium megszerzésére, 36 fö abszolvált (82\%), közülük 13 fő szerzett fokozatot $(29,5 \%)$, és mindössze nyolc fő fejezte be idő elött, abszolutórium nélkül a $\mathrm{PhD}$-tanulmányait (18\%). Ebből a szemszögböl nézve ugyanazt a számsort máris egy egészen magas hatékonysággal müködő doktori iskola képe tárul elénk.

A doktori iskolák működési eredményességének hajszolása úgy tủnik, nem csupán külső (az ODT/MAB által szorgalmazott) kényszer, hanem a doktori iskolák saját érdekében is áll. Ez több okból is szükségképpen a minőségi képzés mennyiségi irányba történő elmozdítását eredményezi. Egyfelöl, az egy intézményre jutó állami ösztöndíjas férőhelyek intézmények közötti elosztása során nevesített keretelosztási szempont a szervezett doktori képzésben részt vevő hallgatók száma, az Egyetemi Doktori Tanács által megítélt összes doktori fokozat száma és a doktori fokozatot szerzettek aránya a képzésbe belépő doktoranduszokhoz képest (40\%-ban figyelembe vett szorzó). ${ }^{13} \mathrm{~A}$ Debreceni Egyetemen működő Társadalomtudományi Doktori Tanácson belül ráadásul az állami ösztöndijas féröhelyek elosztása során már szinte kizárólag az adott doktori iskolában megítélt doktori fokozatok száma az irányadó. ${ }^{14}$ Másfelöl, a törzstagi megfelelőség (és ekként a doktori iskolai müködés) központi eleme, hogy a törzstagnak legyen legalább egy fokozatot szerzett doktorandusza, vagy legalább két fokozatot szerzett hallgatónak társ-témavezetője legyen. ${ }^{15}$ Végezetül, a doktori iskolák müködésének anyagi alapjait közvetlenül vagy közvetve a fokozatot szerzett hallgatók száma határozza meg, részben a megszerzett $\mathrm{PhD}$-fokozatok után járó állami támogatás révén, részben pedig az ennek köszönhetően meghatározott állami ösztöndijas nappali tagozatos féröhelyek száma után járó állami támogatás révén, melynek „forintosítása” jelenleg lehetetlen vállalkozásnak tűnik. ${ }^{16}$

12 A statisztikai adatokból objektív módon megállapítható, hogy abban jelen tanulmány szerzőinek doktori iskolái nem szerepelnek, mert az előadásban kiemelt mindhárom állam- és jogtudományi doktori iskola működését a debreceni és győri doktori iskolát évekkel megelőzően kezdte meg.

13 http://www.doktori.hu/index.php?menuid=351\&cid=24 (2014. 09. 30.).

14 Debreceni Egyetem Társadalomtudományi Doktori Tanács szabályzata, 9. §.

15 A MAB 2014/6/IV. számú határozata, I.1.5. pont.

16 A Debreceni Egyetem Gazdasági Főigazgatóságának tájékoztatása szerint az Emberi Erőforrások Minisztériumától érkező támogatások összege „több elemet tartalmaz összevontan, a Doktori Iskolákra jutó támoga- 
A Marton Géza Doktori Iskola működésének első néhány évében központi szerepet játszott a mennyiségi követelményeknek (konkrétan a törzstagi megfelelőségnek) a teljesítése, olykor meglehetősen abszurd helyzetet eredményezve. A 33/2007. (III. 7.) Korm. rendelet hatályba lépését követően az Országos Doktori Tanács honlapján 2007. december 17-én jelent meg a Magyar Felsőoktatási Akkreditációs Bizottság (a továbbiakban: MAB) 2007/10/III.2. számú határozata a törzstagjelöltek és a doktori iskolák értékelési szempontjairól. ${ }^{17} \mathrm{E}$ határozat 5 . pontja a törzstagi követelményeket a kormányrendelet szövegén túl azzal egészítette ki, hogy a törzstagok formailag csak akkor felelnek meg, ha van PhD-fokozatszerzéssel zárult témavezetői tapasztalatuk (min. 0,5 fö, azaz legalább egy társ-témavezetőként jegyzett fokozatszerzés), jóllehet ilyen feltételt a kormányrendelet nem tartalmazott. ${ }^{18}$ Ezzel kapcsolatosan elgondolkodtató Nagy Marianna érvelése (a 2009. évi doktori iskolai akkreditáció kapcsán), miszerint „a MAB mint quasi autonóm államigazgatási szerv jogalkalmazó és nem jogalkotó szerv, tehát álláspontom szerint nem alkothat jogot, még ha ezt a felsőoktatás színvonalának emelése okán teszi is." ${ }^{19}$ Miként az is tanulságos, hogy a MAB doktori iskolai akkreditációs tárgyú határozatai az Országos Doktori Tanács honlapján a „jogszabályok" menüpontban érhetőek el jelenleg is. ${ }^{20} \mathrm{~A}$ MAB jogállását egyébiránt jelenleg a nemzeti felsőoktatásról szóló 2011. évi CCIV. törvény 70-71/A. szakaszai rendezik.

A MAB 2008/3/VIII/2/128. számú, 2008. március 27-én kelt határozatával a Debreceni Egyetem Állam- és Jogtudományi Doktori Iskolát végül „feltételesen megfelel" minősítéssel akkreditálta, mindenekelőtt azért, mert négy törzstag-jelölt (Fodor László, Horváth M. Tamás, Szabadfalvi József, Várnay Ernő) is „feltételesen megfelelt" minősítést kapott, ugyanis nem rendelkeztek legalább 0,5 fokozatot szerzett hallgatóval. A Doktori Iskola akkori vezetésének álláspontja szerint irreális elvárás volt egy akkor két éve müködő doktori iskolától, hogy kellő számú „saját” védett hallgatót tudjon produkálni, és a MAB által ezen követelmény teljesítésére tüzött 2009. augusztus 31-i határidőben (a debreceni állam- és jogtudományi PhD-képzés harmadik tanévének utolsó napja) sem tủnt reálisan teljesíthetőnek ez az elvárás. Ennek megfelelően a MAB 2009 szeptemberében látogatóbizottság kiküldéséről határozott, melynek feladata az volt, hogy felvegye a kapcsolatot az egyetem rektorával, és tájékozódjon a felmerült hiányosságok adott határidőre történő kiküszöbölésének lehetőségéröl. A Doktori Iskola rendkívül feszített tempóban azon munkálkodott, hogy 2009. november-decemberben két PhD nyilvános vitára is sor kerüljön a

tás összege így nincs külön meghatározva”, az az egyetemen belüli költségvetési alkuk eredményeként kerül meghatározásra, ami feltehetően nem a debreceni PhD-képzés sajátossága, hanem országos jelenség.

17 http://www.doktori.hu/index.php?menuid=351\&cid=81 (2014. 09. 30.).

18 A jelenleg hatályos $387 / 2012$. (XII. 19.) Korm. rendelet 2 . $§(2)$ bekezdés d) pontja már egyértelműen rögzíti, hogy a törzstagokkal szemben elvárás, hogy „témavezetésével legalább egy doktorjelölt doktori fokozatot szerzett”, bár e tekintetben is érdekes logikai gondolatkísérletre adhat lehetőséget a MAB 2014/6/IV. számú határozatának I.1.5. pontja, melynek értelmében vagy egy önálló témavezetéssel, vagy pedig két társ-témavezetéssel fokozatot szerzett doktorandusz a törzstagi megfelelőség feltétele.

19 NAGY Marianna: Jogalkotási és jogalkalmazási kérdőjelek a doktori képzésre vonatkozó jogi szabályozásban egy akkreditációs eljárás apropóján, Magyar Tudomány (2010) 1, 72.

20 http://www.doktori.hu/index.php?menuid=133 (2014. 09. 30.). 
Doktori Iskolában, és ekként Szabadfalvi József és Várnay Ernő is rendelkezzenek fokozatot szerzett hallgatóval. ${ }^{21}$ A fenti elözmények után a MAB plénuma 2010/1/ $\mathrm{XI} / 2 / 353$. számú, 2010. január 22-én kelt határozatával a Debreceni Egyetem Államés Jogtudományi Doktori Iskolájának akkreditációját 2014. december 31-ig megerösítette, miután hét törzstagot is "megfelelt” minősítésünek ítélt.

Meglátásunk szerint, miként azt a debreceni példa is mutatja, az állam- és jogtudományok területén az egyes doktori iskolákban a kellő számú törzstag biztosítása mindenekelött a védett hallgatóra vonatkozó feltétel miatt jelenthet(ett) nehézséget a doktori iskolák és jogi karok számára, különösen a kisebb, és 2000 után létrejött doktori iskolák esetében, és különösen ezen feltétel meglehetősen váratlannak tűnő bevezetésének idején. Abban az esetben azonban, ha egy új akkreditációs feltétel (legyen az akár az éppen hatályban levőnél számottevően szigorúbb is) oly módon kerül bevezetésre, hogy kellő felkészülési időt biztosít az érintettek számára az adott követelmény teljesítésére, valamint a feltétel reálisan valóban teljesíthető és szakmailag indokolható, joggal várható el egy, a színvonalas doktori képzést céljául kitűző intézménytől az, hogy kellő erőfeszítések árán stabilan teljesíteni tudja ezeket a követelményeket. Álláspontunk szerint ilyen szakmailag indokolható és kellő felkészülési időt biztosító követelmény lehet például, hogy a doktori iskolák vezetőinek 2016. január 1-jétöl DSc/MTA doktora tudományos címmel kell rendelkezniük, ${ }^{22}$ bár - Nagy Marianna szavait idézve - az elvárás jogalapja legalábbis vitathatónak tünik ebben az esetben is.

\section{A minőségi szempontok becsatornázásának lehetőségei}

Jóllehet számos tényező szól a doktori képzés „mennyiségi képzés” irányába történő elmozdítása mellett, léteznek olyan belső és külső korlátok is, melyek több-kevesebb sikerrel képesek egyfajta minőségi védőhálót képezni a doktori iskolák müködése körül. Egy PhD-fokozat megszerzése ugyanis a tudományos szcéna íratlan vagy írott elvárásain túl egy jogszabályi, illetve egyetemi normatív környezetben ${ }^{23}$ valósul meg, amelynek intézményesített minőségbiztosításáért a MAB felelős. ${ }^{24}$ A nem intézményesített, a jogszabályoknak való megfelelésen túli szakmai minöségbiztosítás körébe soroljuk a tudományos szféra képviselői részvételével lefolytatott mühelyviták, a doktori szigorlatok és a nyilvános védések körét, valamint azt a folyamatos tevékenységet, amellyel a szakma a publikációs aktivitásban, kuta-

21 2009. november 30-án Fazekas Flóra, 2009. december 16-án Szmodis Jenő Lóránt nyilvános vitájára került sor.

22 A MAB 2014/6/IV. számú határozatának II.2.8. pontja.

23 Jelenleg ez egy általában négyes tagolású normahalmaz, jelesül a nemzeti felsőoktatásról szóló 2011. évi CCIV. törvény; a doktori iskolákról, a doktori eljárások rendjéröl és a habilitációról szóló 387/2012. (XII. 19.) Korm. rendelet; az egyetemi doktori szabályzatok; és az egyes doktori iskolák tudományági (esetleg tudományterületi) doktori szabályzatai.

24 Ugyanakkor az OECD is évröl évre közzéteszi oktatási indikátorait és ezek értékelését, külön is szólva a doktori képzésröl. Lásd pl.: Education at a Glance 2013 - OECD Indicators, http://dx.doi.org/10.1787/eag2013-en, különösen 58-59. és 295-296. (2014. 09. 30.) 
tási-kutatásszervezői tevékenységben és konferencia-előadásokban megnyilvánuló doktori hallgatói munkát figyelemmel kíséri.

A doktori iskolákon belüli minőségbiztosítás folyamata ugyanakkor ennél sokkal összetettebb, ráadásul a fenti célok elérését, a minőségfejlesztést elsősorban a doktori képzési mühelyben elsajátított elvek, ismeretanyag, készségek és képességek, valamint a mentalitás segíti elő. Ezért is kiemelkedően fontos a doktori iskolák iskolateremtő személyiségeinek szerepe a doktori képzésben, akik rendszerint törzstagi, oktatói és témavezetői feladatokat is ellátnak. E ponton pedig - túl a jogszabályi környezeten és a tudományos-akadémiai élet elvárásain - a doktori iskolai szerepfelfogás válik meghatározóvá.

Eme szerepfelfogás számos, kimerítő jelleggel fel nem sorolható módszerben, hangsúlyban ölthet testet. A doktori képzési rendszerek elvi síkon alapvetően három filozófiát hordozhatnak magukban. Eszerint lehetnek: a) a doktori kurzusok hangsúlyos (adott esetben kizárólagos) megjelenítését valló iskolarendszerü képzések; b) a kurzusokat lényegében kiiktató tiszta tutoriális rendszerek, ahol a „képzés” lényegében kutatásmódszertanból és a doktori disszertáció megírásából áll; és c) az előbbiek közötti egyfajta átmenetet jelentő, vagy az elöbbiek vegyítését magában foglaló vegyes rendszerek.

A jelenleg hatályos magyar szabályozás a vegyes rendszert preferálja (az abszolutórium megszerzéséig az iskolarendszerü képzés az irányadó), legalábbis a szervezett doktori képzés keretei között. Míg a normatív előírások fényében az egyetemi doktori szabályzatok általánosságban inkább a kurzusorientált iskolarendszerü metodika irányába mozdítják el a képzést, addig a doktori iskolák szintjén érdemi lehetőség nyílik az inkább tutoriális képzési formák alkalmazására. Ez elsősorban azon ténnyel magyarázható, hogy az egyetemi doktori szabályzatok több tudományterületen és képzési területen szervezett doktori iskolára vonatkozóan írnak elő uniformizált szabályokat, így kevéssé lehetséges például az állam- és jogtudományi és a müszaki doktori képzési területre egyaránt irányadó tutoriális irányokat meghatározni. A speciális, területspecifikus tutoriális elemek megjelenítése sokkal inkább a tudományterületi vagy tudományági doktori iskolák szabályzatai és képzési terve szintjén valósítható meg.

A Debreceni Egyetem Doktori Szabályzata (és ez alapján a Marton Géza Doktori Iskola szabályzata és képzési terve) is egyértelmüen a vegyes rendszert alkalmazza, ám abban az átlagosnál nagyobb hangsúlyt fektet a tutoriális szempontok érvényesítésére. A hat félév során megszerzendő 180 kreditpontból 20 kreditpont a kötelező, illetőleg választható tárgyak súlya, míg 90 kreditpont szerezhető a minden félév során elkészítendő részletes szakmai elörehaladási jelentéssel és annak a kutatási fórumon történő szóbeli megvédésével. A Debreceni Egyetem Doktori Szabályzata 2003-ban még sokkal inkább az iskolarendszerü képzést támogatta: az akkor hatályos szabályok szerint a 180 kreditpontból 70 kreditpontot kellett szerezni a tantárgyak teljesítésével, és csak 40 kreditpontot ért a rendszeres kutatási beszámoló elkészítése és a kutatási fórumon való részvétel. A Doktori Szabályzat ilyetén változása egyúttal a korábban már említett minőségi szempontok háttérbe szorulását is mutatja: míg a 2003-ban hatályos szabályzat szerint oktatási tevékenységért a hat félév során legfeljebb 16 kredit volt adható, addig 2006 óta ez a kreditszám 
már 45, félévenként pedig 8 kreditben került maximálásra (ami gyakorlatilag heti 8 kontaktóra megtartásának felel meg), egyértelmủen az óratartás lehetőségének (kötelezettségének?) irányába mozdítva el a doktoranduszokat és témavezetőiket. Örömteli ugyanakkor, hogy az elmúlt években Debrecenben abszolutóriumot szerzett állami ösztöndíjas nappali tagozatos hallgatók esetében mindössze egy esetben került sor a hat félév alatt összesen 20-nál több oktatási kreditpont elszámolására, azaz a doktoranduszok egy félévre jutó átlagos oktatási tevékenysége jellemzően legfeljebb heti 3-4 órát ért csak el. Említést érdemel, hogy a Jakab Éva által 2010ben készített, valamennyi doktori iskola tevékenységét összehasonlító felmérés szerint messze a debreceni doktori iskolában a legalacsonyabb a tantárgyi követelmények teljesítésével szerezhető kreditpontok száma (20), míg a sorban második Pécsi Tudományegyetem Állam- és Jogtudományi Doktori Iskolájának hallgatói a hat szemeszter alatt legfeljebb 65 tanulmányi kreditpontot szerezhetnek. ${ }^{25}$

\section{A tutoriális elemeket magában hordozó vegyes rendszer jellemzői}

A tutoriális, azaz az oktató és hallgató szorosabb együttmüködésén, az interaktív és intenzív konzultációs tevékenységen, a doktori kurzusok („a mesterszak utáni mesterszak”) elsősorban módszertani tárgyakra való korlátozásán alapuló rendszer „vegytiszta” módon jelenleg nem vezethető be a hazai doktori képzésben, noha ezen elemek mind hangsúlyosabban vannak jelen valamennyi állam- és jogtudományi doktori iskola képzési tervében. ${ }^{26}$

Ahogy az előzőekben jeleztük, a tutoriális elemek megjelenítésének ugyan külső okok, normatív előírások is gátat szabhatnak, a doktori iskolák saját hatáskörben, területspecifikus kutatásmetodológiai és hasonló módszertani képzési formák képében beilleszthetik annak egyes elemeit az iskolarendszerü képzési struktúrába. Kétségkívül ez a trend, illetve a periodikus „elörehaladási jelentések” elkészítése teremtik meg annak alapját, hogy a tutoriális szemlélet minél erőteljesebben jelenjen meg a szervezett képzési időben, hiszen az előrehaladási jelentés összeállítása és rendszeres értékelése során a doktori hallgató és a témavezető együttmüködésre, közös gondolkodásra van „ítélve”, ugyanakkor minőségbiztosítási elvként megjelenhet a jelentések, értékelések egyéb szereplők, tipikusan a doktori iskolai fórum előtt való prezentálása, megvitatása is. ${ }^{27} \mathrm{E}$ képzési forma egyik nagy hátránya viszont, hogy sok esetben olyan speciális ismereteket is igényelhet, amelyeknek a doktori iskolák mégoly kiváló törzstagi és oktatói gárdája sincs feltétlenül birtokában,

25 Lásd a Pécsi Tudományegyetem Állam- és Jogtudományi Kara Doktori Szabályzatának 2. számú mellékletét: http://ajk.pte.hu/doktori-iskola/szabalyzatok (2014. 09. 30.).

26 A PhD-képzés tutoriális változatának két fö pilléréröl - kutatásmódszertan (lábjegyzetelés, pályázatírás, jogtudományi etika stb.) és oktatásmódszertan - és egyes, a célok szintjén létező releváns felvetésekről a doktori iskolák profilját illetően lásd bővebben JAKAB András: A magyar jogi oktatás megújításához szükséges lépések. Reformjavaslat összehasonlító áttekintésre alapozva, Magyar Jog (2010) 4, 214.

27 Az egyéni képzés vagy az egyéni felkészülés mint doktori iskolai képzési „forma” már lényegében kizárólag tutoriális elemeket foglal magában, más kérdés viszont, hogy eme képzési formákban, speciális tagozatokban a doktoranduszok elenyésző számú kisebbsége vesz csak részt. 
így egyes módszertani kurzusok (pl. speciális adatbázisok kezelése) oktatásához, szemléltetéséhez külső szakemberek bevonása indokolt.

A tutoriális képzési forma számos előnye közül a legmarkánsabb a tutor, jelen esetben a témavezető( $k$ ) személye által kínált kivételes lehetőség. A doktori képzés célja a doktori tanulmányokat folytató hallgató számára minden kétséget kizáróan a doktori fokozat megszerzése. Az ehhez vezető úton rendelkezésre áll a doktori iskola szervezeti-intézményes kerete és segítsége, de ennél is fontosabb a témavezető személye, tudományos, tudományszervezői és pedagógiai habitusa (nem hiába hívja a német nyelv a témavezetőt igen szemléletesen Doktorvatemak vagy Doktormuttemek). A tutoriális elemek kibontakoztatásának, gyakorlatban való megvalósulásának kulcsmotívuma a "hallgató-témavezető-doktori iskolai titkárság” triászának együttmüködése. Utóbbi az intézményes, az operatív-szervezési keretek biztosítása révén kerül előtérbe, amely feltétlenül szükséges ahhoz, hogy elöbbi két szereplö, a valódi kulcsszereplők az érdemi tudományos tevékenységet folytatni tudják.

A doktori képzés sikeres müködtetése a normatív korlátokon és lehetőségeken túl feltételez bizonyos adottságokat, paramétereket a doktori iskolák részéről. Eme paramétereket három csoportba sorolhatjuk, tehát a hatékonyság biztosítását szolgálják a) a személyi garanciák; b) a szervezeti garanciák; valamint c) az anyagifinanciális garanciák. Ezek közül a tutoriális képzés kapcsán leginkább az első két garancia érdemes közelebbi vizsgálatra, hiszen ez a fajta képzés vegytiszta formájában kevéssé költség- és infrastruktúra-igényes: lényegében csak a speciális készségtárgyak és egyéb szaktudást igénylő kutatásmódszertani ismeretek külső szakemberek általi oktatása finanszírozandó. ${ }^{28}$

\subsection{A személyi garanciák}

A személyi garanciák körébe sorolható egyrészről természetesen a hallgatói személyi állomány meritokratikus kiválasztása, mely kulcskérdés a doktori képzés sikeressége szempontjából, másrészről a minőségbiztosítás az oktatói, témavezetői állomány kapcsán, a tudományos és pedagógiai, oktatás- és kutatásszervezési habitussal és elhivatottsággal rendelkezőknek a doktori képzésbe való bevonása. A témavezetöi habitus, az oktatói képességek és a kutatói elhivatottság három olyan összetevő, amely eltérő módon van jelen az emberi személyiségben, és egy elismert, jó kutató nem minden esetben rendelkezik kiemelkedő oktatói, retorikai képességekkel. A doktori iskolák számára kulcskérdés, hogy eme habitusok ún. intézményes összessége kiemelkedő és példaértékű legyen, hiszen valamennyi doktori képzési helyen megtalálhatók azok a törzstagok, oktatók, témavezetök, akik ezekkel

28 E körben a tudományos repozitóriumok - könyvtári állomány, elektronikus adatbázisok (pl. JSTOR, EBSCO, WestLaw, HeinOnline, Jogkódex stb.) - persze valódi és számottevő költséget jelentenek, föleg a tutoriális képzésben, de ez valójában a doktori iskolán kívüli anyagi kérdés, hiszen a repozitóriumokat tipikusan egyetemi szinten tartják fent. Ezek beszerzése tehát mindig nagyban függ a hatályos közbeszerzési normakörnyezettől és a rendelkezésre álló vagy megszerzett pályázati forrásoktól. 
hangsúlyosabban rendelkeznek. Mindez már rövidtávon is értékes, kiemelkedő képességủ hallgatókat vonz a képzési helyhez vagy egy adott témavezetőhöz, akikkel a sikeres fokozatszerzés és a színvonalas oktatói-tudományos munka egyértelmüen biztosítható.

Fontos szempont továbbá, és nevesített MAB-elvárás is, hogy a törzstagok kutatási területei lényegében valamennyi fontosabb jogágat (alkotmányjog, állam- és jogelmélet, büntetőjog, európai és nemzetközi jog, jogtörténet, közigazgatási jog, polgári jog stb.) lefedjék. Vezető oktatók és kutatók lévén általános trend továbbá, hogy a törzstagok egyben tanszéket is vezetnek, amely további jogágak (pl. eljárásjogok) tekintetében is feltételez szakmai ismereteket, széleskörü oktató- és kutatótevékenységet. Nem kétséges, hogy az egyéni, szakmai előmeneteli lehetőségeken túl a széles kutatási paletta és a lehető legtágabb oktatási portfólió vonzza a doktori képzésre a hallgatókat. Ugyanakkor minden doktori iskola (a karokkal egyetemben) az oktatói és kutatói utánpótlásra is kiemelt figyelmet fordít. Az oktatói utánpótlás bizonyítéka, hogy az oktatók és témavezetők között számos fiatal, tipikusan adjunktusi és docensi beosztású személy található, akik már idejekorán bekapcsolódhatnak a doktori iskolák munkájába. Hosszabb távon ez kétségkívül előnyökkel járhat, hiszen a speciális doktori képzési „előmenetel” lehetővé teszi, hogy mindenekelőtt oktatóként (választható tárgyat jegyezve) kezdje meg a munkát a fiatal, tudományos fokozattal rendelkező munkatárs, majd bizonyos tapasztalatszerzés után témavezetőként segítse a hallgatót. Eme tapasztalatok megszerzése után már érett kutatóként (a tudomány- és oktatásszervezés területén is jelentős jártassággal bírva) vehet részt a doktori iskola müködésében és müködtetésében, immár törzstagként. Ez a folyamat egy ideáltipikus karrierútnak tekinthető a doktori iskola „személyzeti politikájában".

A társadalomtudományi területen - de talán nem túlzás azt állítani, hogy leginkább az állam- és jogtudományok területén - a rendszerváltás idején és az azt követő első években számos tehetséges fiatal pályakezdő hagyta el az egyetemi-tudományos szférát, hogy immáron demokratikus viszonyok között a gyakorlati életben (döntően klasszikus jogászi hivatásrendekben, minisztériumi munkában stb.) kamatoztassa tudását. Ez azzal a következménnyel járt, hogy szinte egy egész generáció hiányzik az akadémiai szcénából. Ez „demográfiailag” azt jelenti, hogy a rutinos, érett kutatói kör (tipikusan egyetemi tanári kör, közöttük számos akadémiai doktor) és a fiatal, pályakezdő, legfeljebb adjunktusi vagy „kezdő”, iskolateremtői, témavezetői tapasztalatokkal még nem rendelkező docensi beosztású oktatók-kutatók között igen nagy a „tudományos szakadék”, ${ }^{29}$ így az átmenetet biztosítani hivatott középgeneráció (45-55 év közöttiek) csekély számban van jelen a doktori iskolák életében. Ez a megállapítás a legtöbb állam- és jogtudományi kar oktatói állományára is igaz, ezért a mai napig számos állam- és jogtudományi kar korfája is ún. homokóra-alakot mutat.

A Marton Géza Állam- és Jogtudományi Doktori Iskola gyakorlatában a felvázolt személyi működési keretek javarészt objektív szempontokon alapuló, transzparens módon biztosítottak. A PhD-képzésbe jelentkezők teljesítményének értékelése során

${ }^{29}$ Az oktatói képességekre mint második habitusi körre ez a megállapítás már nem feltétlenül igaz. 
kizárólag a jelentkező szakmai elóélete, a kutatási terv szakmai megalapozottsága, illetőleg a jelentkező felkészültsége (beleértve az idegen nyelvi felkészültséget is) játszanak szerepet. Az ezen előfeltételekre kihegyezett felvételi elbeszélgetés kétségkívül jelentősen csökkenti a szubjektív elemeket, azonban részben a PhD-képzés jogásztársadalmon belüli viszonylag alacsony (bár az utóbbi időben, például a bírósági-ügyészségi előmenetel során lassan növekvő mértékű) presztízse, részben a Debrecenben 1996 óta vállalt viszonylag alacsony évfolyam-létszámok (100-150 fő között mozgó nappali tagozatos joghallgatói évfolyamok), részben a doktori iskola egyre javuló eredményessége ellenére lassan növekvő állami ösztöndíjas nappali tagozatos férőhelyek száma miatt igazi versenyhelyzet a nappali tagozatos jelentkezők között csak ritkán alakul ki.

A korábbiakban már említett, a törzstagi megfelelösséggel kapcsolatos problémák, úgy tünik, a Marton Géza Doktori Iskola és az Állam- és Jogtudományi Kar vezetése átgondolt lépéseinek köszönhetően megoldódnak, hiszen a 2014. őszi akkreditációt megelőzően a doktori iskola összesen 10 „megfelelt” minősítésü törzstaggal rendelkezik. Az említett homokóra-alak azonban a debreceni doktori képzésben is megfigyelhető: jelenleg egyetlen debreceni jogi doktori iskolai törzstag sem található a 42-52 év közötti életkori tartományban. Bár a témavezetői utánpótlás tervezett felépítése minden doktori iskola számára rendkívül fontos a majdani törzstagság elnyerése és ezáltal a doktori iskola müködése szempontjából, a debreceni gyakorlat legalábbis felülírni látszik az előzőekben vázolt, mondhatni ideáltipikus oktatói előmenetelt. A Marton Géza Doktori Iskola szabályzata és gyakorlata szerint a témavezetői névjegyzékbe történő felvétel feltétele, hogy a témavezetö-jelöltet a doktori iskola tanácsa indokolt javaslatára a Társadalomtudományi Doktori Tanács a tudományos és publikációs tevékenysége alapján alkalmasnak tartsa arra, hogy a doktoranduszok tudományos munkáját irányítsa, ami a gyakorlatban a PhD-fokozat megszerzése után legalább három éven keresztül folytatott magas színvonalú tudományos tevékenységet és ezáltal a szakmai közéletben történő jelenlétet és elfogadottságot követel meg. Mivel a PhD-képzésben tárgyjegyzőként többnyire a tudományosan legelismertebb témavezetők vesznek részt, ekként a doktori képzésben történő tárgyjegyzés nem előzménye, hanem következménye lehet a témavezetői névjegyzékbe történő felvételnek, azaz választható tárgyat a PhD-képzésben csak olyan oktató jegyezhet, aki már a témavezetői névjegyzékbe korábban felvételre került. Általános tendencia ugyanakkor, hogy miközben a témavezetöi névjegyzék bővítése mellett szól az emelkedő hallgatói létszám és egyes oktató kollegák leterheltsége, ennek a folyamatnak nem szabad odáig vezetnie, hogy a témavezetőkkel szembeni minőségi elvárások háttérbe szoruljanak. 


\subsection{A szakmai és szervezeti garanciák}

A szakmai-szervezeti garanciák közé elsősorban a kiválasztási szempontokat, a doktori iskolák létszáma adta kereteket, a módszertani hangsúlyokat, valamint a pályakövetési és az egyéb visszacsatolási lehetőségeket soroljuk.

A doktori iskolák szervezett képzésébe kizárólag transzparens és meritokratikus elveken nyugvó felvételi eljárás útján lehet bekerülni. A felvételi eljárásban alkalmazott, pontosan szabályozott értékelési kritériumok és a felvételi bizottság pártatlansága egyaránt biztosítékul szolgálnak arra, hogy csak a legkiválóbb és legelhivatottabb jelentkezők kezdhessék meg doktori tanulmányaikat. A felvételi pontszámok és követelmények, amelyekröl a tanulmányi és vizsgaszabályzatok rendelkeznek, nyilvánosak, rendszerint az egyetemek és/vagy a doktori képzések honlapjairól is letölthetők. A jelentkezők értékelése során különös hangsúlyt kap a jelentkező tanulmányi eredménye, idegennyelv-ismerete, esetleges tudományos diákköri vagy demonstrátori munkája, külföldi részképzése, addigi publikációs tevékenysége, kutatási programokban való közremüködése, (tipikusan hallgatói) konferenciákon való részvétele, valamint az elöterjesztett munkaterv tudományos megalapozottsága és megvalósíthatósága.

Az állam- és jogtudományi képzési helyek létszámbeli adottságait ${ }^{30}$ döntően befolyásolja a képzési hely állam- és jogtudományi karának hallgatói létszáma, a régió elhelyezkedése és tudományos „fokozatfelszívó-képessége”, ${ }^{31}$ illetve a doktori iskola filozófiája. A kisebb létszámmal dolgozó doktori iskolák filozófiájára jellemző a tutoriálisabb, több érdemi és közvetlen konzultációs lehetőséget magában hordozó modell kialakítása, a sokat és sokszor érdemtelenül „pellengérre állított” tömegtermelés kétségkívül negatív hatásainak, velejáróinak szándékolt kiiktatása. ${ }^{32} \mathrm{~A}$ képzési filozófia és modell jogszabályi keretek közötti kialakítása kétségkívül olyan kérdés, amelyet a doktori iskola indulásakor, és lényegében valamennyi új tanévben, esetleg a felsőoktatási jogszabályok változásakor a doktori iskoláknak értékelni és mérlegelni kell, sok esetben pedig ezek eleve újragondolásra szorulnak. Fontos azt is megjegyezni, hogy a PhD-képzésnek már nem lehet egyedüli szerepe az utánpótlás és az akadémiai kutatók képzése - a doktoranduszoknak egyre több olyan speciális készséget, képességet kell elsajátítaniuk, amelyek a piaci szektor igényeihez

30 Itt a hallgatói összlétszámra gondolunk, és nem arra, hogy pl. a nappali tagozatos doktoranduszok száma központilag, majd egyetemi szinten kerül (f)elosztásra a tudományterületek, esetleg tudományágak között, részben a korábban már említett szempontok szerint.

31 E kategóriába sorolhatók a következő ismérvek: kutatóintézetek, egyéb kutatóhelyek és egyetemek elhelyezkedése a régióban; kutatási pályázatok célirányai a régióban; határmenti képzési helyek esetében a határon túli együttműködési formák; adott esetben egy előmeneteli lehetőséget kínáló ítélőtábla léte is a régióban, ha megfelelően honorált a bírósági fogalmazók és titkárok körében a fokozatszerzés stb.

322013 áprilisában érdekes írás jelent meg e témában: MASLEN, Geoff: More Countries Are Asking Whether They Produce Too Many Ph.D.'s, Says New Report, http://chronicle.com/article/Report-Examines-theGlobal/138439/ (2014. 10. 01.). 
is igazodnak, hiszen a fokozatot szerzettek közül számosan a piaci versenyszektorban fognak elhelyezkedni. ${ }^{33}$

Nem kétséges az sem, hogy a kutatáshoz és oktatáshoz nélkülözhetetlen módszertani tárgyak képzési kínálata bővül. Valamennyi doktori iskola mind a tapasztalatszerzés, mind a minőségbiztosítás, mind a tudományos előmenetel szempontjából lényegesnek tartja a hallgatók külföldi részképzését, amelynek beszámításához azonban - ugyancsak minőségbiztosítási célból - szigorú feltételeket támasztanak. A kutatás metodológiája azonban mégiscsak egy olyan speciális terület, amely iskolai keretek között egy bizonyos szintig jól megtanulható, ezen túl azonban már nagyrészt egyéni habitus és a tutor/témavezető személyes és akadémiai impaktjának, hozzáállásának függvénye. E vonatkozásban tehát a tutoriális képzési elem egy valódi előfeltétele a sikeres fokozatszerzésnek.

A visszacsatolási és pályakövetési kérdések (megint csak jogszabályi előírásokon és egyetemi belső irányelveken túl) egyfajta minőségbiztosítási garanciával is bírnak, hiszen a hallgatóknak rendszeres idöközönként (félévente vagy évente) kutatási („előrehaladási”) jelentést kell készíteniük, melyet a témavezető véleményez, és amely archiválási céllal a doktori iskolai titkárságokon megőrzésre kerül. Az oktatók hallgatók általi véleményezése a felsőoktatásban már régóta ismert és elektronikusan dokumentált módszer, csakúgy mint a fokozatszerzés releváns fázisaiban (mühelyvita, doktori szigorlat, nyilvános védés) a külső szakemberek bevonása, illetve a pályakövetési rendszer müködtetése, évenként történő frissítése és aktualizálása. Ezen kívül ide sorolható a doktori iskolák honlapjainak állandó frissítése, illetve a képzési helyeknek a közösségi oldalakon való megjelenítése, a fontosabb információkról való tájékoztatás és a minél nagyobb potenciális hallgatói kör elérése érdekében.

A Marton Géza Doktori Iskola müködésére vetítve ezen szakmai-szervezeti garanciák közül terjedelmi okokból csupán eggyel, a külső szakemberek (és ezáltal a nyilvánosság) szerepével foglalkozunk részletesebben. A külső szakemberek PhDeljárásokba (és ezen belül is hangsúlyosan a nyilvános vitára) történő bevonásának szabályait a 387/2012. (XII. 19.) Korm. rendelet részben a hivatalos bírálókra (opponensekre), részben a bírálóbizottság összetételére vonatkozóan határozza meg. A kormányrendelet értelmében a két hivatalos bíráló egyike „nem állhat foglalkoztatásra irányuló jogviszonyban a doktori iskolát müködtető felsőoktatási intézménynyel", míg a bírálóbizottság összetételével kapcsolatosan az a (kormányrendeletben többszörös visszautalással fellelhető) szabály érvényesül, hogy a bírálóbizottság egyharmada, vagy legalább két fő minősüljön külsősnek. A már idézett, Jakab Éva által készített, 2010. nyári állapotokat tükröző összehasonlító táblázat alapján kijelenthetö, hogy a legtöbb állam- és jogtudományi doktori iskola törekszik arra, hogy a nyilvános vitára felkért mindkét bíráló külső szakember legyen, mely tendenciát a Marton Géza Doktori Iskola is maradéktalanul teljesíti, sőt 2009 óta valamennyi Debrecenben szervezett $\mathrm{PhD}$ nyilvános vita bírálóbizottságban többségben voltak

33 Erröl lásd bövebben: MeLIN, Göran-JANSON, Kerstin: What Skills and Knowledge Should a PhD Have? Changing Preconditions for PhD Education and Post Doc Work. In: Teichler, Ulrich (ed.): The Formative Years of Scholars, London, Portland Press, 2006, 105-118. 
az egyetemtöl független külső szakemberek. ${ }^{34}$ Deklaráltan ugyanezt a gyakorlatot követi például a Széchenyi István Egyetem Állam- és Jogtudományi Doktori Iskolája is, ekként a jelenség az állam- és jogtudományi doktori iskolák között korántsem tekinthető egyedinek.

A nyilvánosság további erősítését szolgálhatná ugyanakkor az a gyakorlat, ha nem csupán az értekezések, ${ }^{35}$ hanem az opponensi vélemények is nyilvánosak lennének, erre azonban tudomásunk szerint egyetlen állam- és jogtudományi doktori iskolában sincs jelenleg precedens. ${ }^{36}$ Ugyancsak a nyilvánosság és ezáltal a szakmai színvonal erősítését szolgálja a doktorjelölttől a fokozat megszerzésének feltételeként elvárt önálló tudományos munkásság követelményének egyértelmü rögzítése. A már idézett, Jakab Éva által 2010. novemberében készített javaslat szerint a nyilvános vita kitǔzéséhez a jelöltnek legalább hat tudományos cikk publikálása és legalább 1-2 tudományos konferencia-előadás lenne a minimális elvárás. A Marton Géza Doktori Iskola gyakorlata alapján szerencsésebbnek tartjuk, ha a jelölttől elvárt tudományos publikációkat nem csak mennyiségi alapon, de részben a terjedelmük (legalább 30 ezer leütés), részben pedig a megjelenés helye (az MTA Állam- és Jogtudományi Bizottsága szerint legalább $B$ kategóriába sorolt hazai tudományos folyóirat, egyedi esetekben kivételesen lektorált könyvfejezet) szerint is meghatározzuk. E tekintetben a Debreceni Egyetemen belül is kimagasló a Marton Géza Doktori Iskola hallgatóinak publikációs tevékenysége: a 2013. december 31-ig (a Tudományegyetemi Karok szervezeti egység megszünéséig) létező Debreceni Egyetem Tudományegyetemi Karok Év Hallgatói Tudományos Publikációja Aranyérem kitüntetést 2008 és 2013 között hatból öt alkalommal elnyerte a Marton Géza Doktori Iskola valamely hallgatója, jóllehet a Debreceni Egyetemen jelenleg is 25 doktori iskola müködik (közülük pedig tizenegy tartozott a Tudományegyetemi Karok szervezeti egységhez).

\section{Konklúzió helyett}

Reményeink szerint az olvasó tanulmányunkból képet kaphatott arról, mire számíthat általában, ha ma Magyarországon állam- és jogtudományi doktori képzésre (esetleg egy ilyen képzésben oktatóként, témavezetőként történő részvételre) adja a fejét, illetőleg mennyiben tér el ettől (ha eltér egyáltalán) a Debreceni Egyetem Marton Géza Állam- és Jogtudományi Doktori Iskolájának müködése. Bár a PhD-képzés

34 Az egyes bírálóbizottságok összetétele megismerhető a doktori iskola honlapján fellelhető meghívókból: http://jog.unideb.hu/doktori/korabbi-doktori-cselekmenyek (2014. 09. 30.).

35 Megjegyezzük, hogy van olyan állam- és jogtudományi doktori iskola, mely az interneten nem hozza teljes terjedelmében nyilvánosságra a doktori értekezések szövegét, miközben a nemzeti felsőoktatásról szóló 2011. évi CCIV. törvény 53/A. § (2) bekezdése meglehetősen egyértelmüen fogalmaz ebben a kérdésben: „A doktori értekezést és téziseit elektronikus formában a Magyar Tudományos Művek Tárában, az általánosan elfogadott nemzetközi gyakorlatnak megfelelő (DOI) azonosítóval ellátva, mindenki számára hozzáférhetővé kell tenni."

36 Jakab Éva a Jogász Dékáni Kollégium 2010. november 12-i ülésére készített előterjesztésében kifejezetten javasolta az opponensi vélemények nyilvánosságra hozatalát. 
egyébként is rögös útján elhelyezett akadályok folyamatosan változnak és egyre újabbak bukkannak fel, a jogi karok és doktori iskolák feladata, hogy az akadályokat leküzdve próbálják megfelelő irányba navigálni a PhD-képzés hajóját, mert ez nem csupán az intézmények, hanem az oda tartozó oktatók és hallgatók olyan közös érdeke is, ami alkalmas az adott tudományág és intézmény nemzetközi térképekre történő felhelyezésére is. Éppen ezért reméljük, hogy tanulmányunk képes volt felvázolni a doktori képzés és doktori iskolai müködés lehetséges irányait, hiszen - miként Bazsa György, a MAB akkori elnöke is írta egy néhány évvel ezelötti, a doktori képzés és a MAB szerepét értékelő írásának címében -: navigare necesse est. ${ }^{37}$

\begin{abstract}
In this study the authors (Gábor Kecskés as the secretary of Doctoral School of Legal Studies at István Széchenyi University and Sándor Szemesi as the secretary of Géza Marton Doctoral School of Legal Studies at Debrecen University) examine the legal framework concerning doctoral schools of legal studies in Hungary as well as the specialties (and realities) of Géza Marton Doctoral School at Debrecen University. One of the main purposes of this article is to salute the beginning of the $100^{\text {th }}$ academic year at Debrecen University, additionally the article tries to introduce how doctoral schools can fulfil the continuously changing (more precisely, tightening) requirements of the Hungarian Accreditation Committee, taking into consideration the unwritten expectations as well as the general interests of the host universities and the doctoral school itself.
\end{abstract}

37 BAZsA György: Navigare necesse est, Magyar Tudomány (2010) 1, 74-80. 